Jurnal Ekonomi dan Industri

Volume 20, No. 1, Januari-April 2019

p-ISSN : 0853-5248

\title{
PENGARUH BOOK VALUE, DEBT TO EQUITY RATIO, DAN PRODUK DOMESTIK BRUTO TERHADAP EARNING PER SHARE PT.UNILEVER INDONESIA. TbK
}

\author{
Rosdiana *) \\ ${ }^{*}$ Dosen Program Studi Manajemen FE UNKRIS \\ Alamat: Kampus UNKRIS, Jatiwaringin Jakarta Timur \\ Email: rosdiana.da@gmail.com
}

\begin{abstract}
This research intended to further examine whether firm financial performance and economic macro indicators such Book Value, Debt to Equity Ratio and Gross Domestic Bruto have a positive or negative impact Earning Per Share in PT.Unilever Indonesia,Tbk. During period 2006-2015, with the analysis of data using multiple regression with $F$ test to analyze the effect of simultaneous. The research showed that Book Value, Debt to Equity Ratio and Produk Domestik Bruto has significant influence toward Earning Per Share.
\end{abstract}

Keyword: Book Value, Debt to Equity Ratio, Produk Domestik Bruto and Earning Per Share.

\section{PENDAHULUAN}

Krisis keuangan global pada pertengahan tahun 2008 menyebabkan begitu banyak perusahaan serta lembaga perbankan yang bertumbangan. Krisis yang terjadi secara global merupakan dampak dari krisis keuangan yang berlansung di Negara Amerika Serikat, yang dikenal dengan subprime mortgage, yang menyerang sektor property dan melibatkan lembaga keuangan berskala besar di AS, Eropa, dan Jepang. Kredit keuangan tersebut memberikan dampak besar terhadap pertumbuhan ekonomi, dimulai dari penurunan tingkat produksi, kenaikan risiko kredit macet, penurunan tingkat konsumsi dan produksi, meningkatnya tingkat pengangguran, sehingga pada akhirnya akan mengganggu sektor riil. Dari sektor industry juga terkena dampak besar sehingga menyebabkan turunnya kinerja perusahaan dan harga saham.

Pemerintah dan bank sentral AS pada saat itu mengambil langkah cepat untuk menyelamatkan perekonomian dengan mengeluarkan kebijakan moneter yang tidak biasa, dikenal dengan quantitative easing, untuk meningkatkan likuiditas dengan menambah jumlah uang beredar untuk membeli surat hutang pemerintah sehingga pada akhirnya dana tersebut dapat mengalir kembali ke sektor riil. Selain itu, tingkat suku bunga juga didorong mendekati nol untuk mengurangi tekanan di sisi perbankan. Di sisi lain, karena terjadinya genjotan likuiditas di Negara AS selama beberapa tahun, maka terjadi capital outflow ke Negara-negara berkembang, selain juga karena tingkat suku bunga di Negara berkembang jauh lebih menarik daripada di negaranya sendiri.

Kebijakan moneter AS yang dilakukan pada saat itu pada akhirnya memberikan capital inflow kepada perekonomian Indonesia melalui investasi lansung dan portofolio ke dalam pasar modal Indonesia, hal ini dapat dilihat dari meningkatnya tingkat produk domestik bruto Indonesia pada Tahun 2007 - 2009. 
Tabel Laju Pertumbuhan dan Sumber Pertumbuhan PDB Tahun 2007 - 2009

\begin{tabular}{lccccc}
\hline Komponen & \multicolumn{2}{c}{$\begin{array}{c}\text { Atas Dasar } \\
\text { Harga Berlaku } \\
\text { (Trilliun Rupiah) }\end{array}$} & $\begin{array}{c}\text { Laju } \\
\text { Pertumbuhan } \\
\text { (Persen) }\end{array}$ & $\begin{array}{c}\text { Sumber } \\
\text { Pertumbuhan } \\
\text { (Persen) }\end{array}$ \\
\hline & \multicolumn{1}{c}{2007} & 2008 & 2009 & 2009 & 2009 \\
\hline Konsumsi RT & \multicolumn{1}{c}{$(2)$} & \multicolumn{1}{c}{$(3)$} & $(4)$ & $(5)$ & $(6)$ \\
Konsumsi Pemerintah & 2510,5 & 3000,0 & 3290,8 & 4,9 & 2,8 \\
PMTB & 329,8 & 416,9 & 539,8 & 15,7 & 1,3 \\
Perubahan Inventory & 985,6 & 1370,6 & 1743,7 & 3,3 & 0,8 \\
Diskrepansi Statistik & $-1,1$ & 5,8 & $-5,5$ & $-121,9$ & $-0,1$ \\
Ekspor & $-33,6$ & 105,9 & $-112,4$ & $-104,2$ & $-1,4$ \\
Impor & 1163,0 & 1475,1 & 1354,2 & $-9,7$ & $-4,8$ \\
\hline PDB & 1003,3 & 1422,9 & 1197,2 & $-15,0$ & $-5,9$ \\
\hline
\end{tabular}

Pertumbuhan ekonomi Indonesia pada tahun 2009 tercatat sebesar 4,5 persen. Pertumbuhan ini didukung oleh beberapa komponen, yakni konsumsi rumah tangga tumbuh sebesar 4,9 persen, konsumsi pemerintah sebesar 15,7 persen, pembentukan modal tetap bruto sebesar 3,3 persen. Beberapa komponen lainnya mengalami pertumbuhan negatif yaitu ekspor barang dan jasa sebesar minus 9,7 persen dan perubahan inventori yang tumbuh negatif sebesar 121,9 persen. Impor juga menurun sebesar 15,0 persen. Pertumbuhan ekonomi tahun 2009 sebesar 4,5 persen sebagian besar bersumber dari komponen konsumsi rumah tangga yakni 2,8 persen. Konsumsi pemerintah memberikan sumbangan sebesar 1,3 persen, PMTB sebesar 0,8 persen, sementara sumbangan ekspor sebesar minus 4,8 persen

Untuk memberikan dampak positif pada sektor riil, kebijakan investasi dapat difokuskan kepada sektor-sektor industry yang dapat menciptakan lapangan pekerjaan baru dan produknya dibutuhkan oleh masyarakat luas, sehingga tingkat konsumsi dapat meningkat. Salah satu industry yang memberikan kontribusi terbesar pada pertumbuhan ekonomi adalah industry barang dan jasa yang dikonsumsi masyarakat, dan perusahaan yang sebagian besar produknya dimiliki oleh masyarakat untuk dikonsumsi adalah PT. Unilever Indonesia.

Pasar modal sebagai tempat terjadinya transaksi efek merupakan sarana alternative bagi perusahaan untuk mendapatkan tambahan dana bagi pengembangan bisnis perusahaan. Dalam aktivitas pasar modal, harga saham merupakan faktor yang sangat penting dan harus diperhatikan oleh investor dalam melakukan investasi. Apabila emiten mempunyai prestasi yang semakin baik maka keuntungan yang dapat dihasilkan dari operasi usaha semakin besar.

Pada kondisi yang demikian, harga saham emiten yang bersangkutan cenderung naik. Harga saham juga menunjukkan nilai suatu perusahaan. Brigham and Houston (2010) menunjukkan bahwa harga saham akan menentukan kesejahteraan pemegang saham, selain itu harga saham juga berpengaruh secara signifikan terhadap proses income smoothing dalam perusahaan (Suparningsih et al, 2018). Sehingga sering kali dikatakan memaksimumkan nilai perusahaan juga berarti memaksimumkan kekayaan pemegang saham. Oleh karena itu, setiap perusahaan yang menerbitkan saham sangat memperhatikan harga sahamnya. Harga yang terlalu rendah sering diartikan bahwa kinerja perusahaan kurang baik. Namun bila harga saham terlalu tinggi mengurangi kemampuan investor untuk membeli sehingga menimbulkan harga saham sulit untuk meningkat lagi. 
Dalam penelitian ini faktor yang perlu dipertimbangkan dalam pencapaian Earning Per Share adalah Book Value atau nilai buku adalah asset atau kekayaan bersih yang dimiliki perusahaan sebagai tolak ukur untuk menilai harga saham. Debt to Equity Ratio mencerminkan kemampuan perusahaan dalam memenuhi kewajibannya yang ditunjukkan oleh beberapa bagian dari modal sendiri atau ekuitas yang digunakan untuk membayar hutang.

Rasio ini menunjukkan komposisi atau struktur modal dari total pinjaman (hutang) terhadap total modal yang dimiliki perusahaan. Semakin tinggi debt to equity ratio menunjukkan komposisi total hutang (jangka pendek maupun jangka panjang) semakin besar dibanding dengan total modal sendiri, sehingga berdampak semakin besar beban perusahaan terhadap pihak luar (kreditur) (Ang, 1997).

Berhubungan dengan latar belakang tersebut diatas, penelitian ini dilakukan untuk menganalisis pengaruh variabel rasio-rasio keuangan yaitu rasio Book Value, Debt to Equity Ratio,dan Produk Domestik Bruto terhadap Earning Per Share PT Unilever Indonesia Tbk periode Tahun 2006-2015

\section{LANDASAN TEORI}

\section{Book Value}

Menurut (Sihombing, 2008) Book Value (BV) atau nilai buku suatu perusahaan adalah modal pemegang saham (shareholder's equity). Modal pemegang saham jumlah asset - asset perusahaan (company's assets) dikurangi dengan kewajiban. Menurut (Jogiyanto,1998) nilai buku (book value) per lembar saham menunjukkan aktiva bersih ( net assets ) yang dimilik oleh pemegang saham dengan memiliki satu lembar saham.

\section{Debt to Equity Ratio}

Debt to Equity Ratio mencerminkan kemampuan perusahaan dalam memenuhi kewajibannya yang ditunjukkan oleh beberapa bagian dari modal sendiri atau ekuitas yang digunakan untuk membayar hutang. Debt to Equity Ratio merupakan perbandingan antara total hutang yang dimiliki perusahaan dengan total ekuitasnya. Secara matematis Debt to Equity Ratio dapat diformulasikan sebagai berikut (Ang, 1997) :

Total debt merupakan total liabilities (baik hutang jangka pendek maupun jangka panjang), sedangkan total equity merupakan total modal sendiri yang dimiliki perusahaan. Rasio ini menunjukkan komposisi atau struktur modal dari total pinjaman (hutang) terhadap total modal yang dimiliki perusahaan. Semakin tinggi debt to equity ratio menunjukkan komposisi total hutang (jangka pendek maupun jangka panjang) semakin besar dibanding dengan total modal sendiri, sehingga berdampak semakin besar beban perusahaan terhadap pihak luar (kreditur) (Ang, 1997).

Semakin besar hutang, semakin besar resiko yang ditanggung perusahaan. Oleh sebab itu perusahaan tetap mengambil hutang sangat tergantung pada biaya relative. Biaya hutang lebih kecil daripada dana equitas. Dengan menambahkan hutang kedalam neracanya, perusahaan secara umum dapat meningkatkan profitabilitas, yang kemudian menaikkan harga sahamnya, sehingga meningkatkan kesejahteraan para pemegang saham dan membangun potensi pertumbuhan yang lebih besar. Sebaliknya biaya hutang lebih besar daripada dana ekuitas. Dengan menambahkan hutang kedalam neracanya, justru akan menurunkan profitabilitas perusahaan (Walsh, 2004). 
Kemampuan suatu perusahaan untuk mebayar hutang-hutangnya menunjukkan solvabilitas suatu perusahaan. Perusahaan yang solvable berarti perusahaan tersebut mempunyai aktiva atau kekayaan yang cukup untuk membayar semua hutang-hutangnya (Riyanto, 1996). Sejalan dengan uraian diatas, debt to Equity Ratio menunjukkan struktur permodalan auatu perusahaan yang merupakanperbandingan antara total hutang dengan ekuitas yang digunakan sebagai sumber pendanaan perusahaan.

\section{Produk Domestik Bruto}

Menurut (fabozzi, 1990) PDB adalah alat ukur produksi total barang dan jasa di dalam suatu perekonomian

Menurut (Mankiw, 2000) PDB dapat diartikan sebagai nilai pasar dari semua barang dan jasa yang diproduksi di suatu Negara dalam kurun waktu tertentu. Sebagai alat pengukur dalam pertumbuhan ekonomi PDB memiliki empat komponen yaitu : konsumsi rumah tangga, investasi, konsumsi pemerintah, ekspor bersih yang merupakan selisih dari total ekspor dan impor.

\section{Earnings per Share}

Earnings per Share merupakan perbandingan antara pendapatan yang dihasilkan (laba bersih) dan jumlah saham yang beredar. Earnings per Share menggambarkan profitabilitas perusahaan yang tergambar pada setiap lembar saham. Earnings per Share dihitung dengan rumus berikut (Tjiptono Darmadji dan Hendy M. Fakhruddin, 2006) :

Penelitian terdahulu oleh Iqbal Widya Nanda (2011), Berdasarkan hasil uji secara parsial DER berpengaruh negative tidak signifikan terhadap EPS, ROA berpengaruh positif dan signifikan terhadap EPS serta ROE berpengaruh positif dan signifikan terhadap EPS. Oleh karena itu peneliti tertarik untuk menambahkan variabel Book Value dan Produk Domestik Bruto dengan DER terhadap EPS, yang memungkinkan DER berpengaruh positif terhadap EPS.

\section{METODE PENELITIAN}

Penelitian ini menggunakan pendekatan explanatory analysis. hubungan kausal variabel independent terhadap variabel dependent. Data yang digunakan adalah data sekunder yang diperoleh dari library research. Teknik analisa data dengan menggunakan regresi berganda.

\section{HASIL DAN PEMBAHASAN}

\section{Hasil Penelitian}

Pengaruh Book Value, Debt Equity to Ratio, dan Produk Domestik Bruto terhadap Earning Per Share PT Unilever Indonesia Tbk secara simultan.

\begin{tabular}{|c|c|c|c|c|c|c|}
\hline \multirow{2}{*}{$\begin{array}{c}\text { Hubungan } \\
\text { Variabel }\end{array}$} & \multicolumn{6}{|c|}{ Parameter } \\
\hline & $\mathbf{R}$ & R Square & Konstanta & Koef. B & Sig. & $\mathbf{A}$ \\
\hline
\end{tabular}






Pengujian Signifikansi

F hitung $>$ F Tabel $=21.148>3.24$

Berdasarkan tabel diatas maka model yang diperoleh untuk menunjukkan pengaruh Book Value, Debt Equity to Ratio, dan Produk Domestik Bruto terhadap Earning Per Share adalah :

$\mathrm{Y}=-\mathbf{1 3 3 6 0 , 5 3}-1,779(\mathrm{BV})-\mathbf{1 6 8 , 6 7 2}(\mathrm{DER})+\mathbf{2 3 9 0 , 0 4 4}(\mathrm{PDB})$

\section{Pembahasan}

Persamaan regresi berganda simultan dapat dilihat arah hubungan yang dihasilkan dari variabel bebas terhadap variabel terikatnya, dengan asumsi variabel lain (kebijakan makro ekonomi adalah konstan, yaitu:1) Koefisien regresi variabel $\mathrm{X}_{1}$ bertanda negatif menunjukkan adanya hubungan yang negatif dari variabel Book Value yang menyebabkan penurunan sebesar -1,779 dan signifikan untuk prob sig 0.000 (signifikansi untuk $\alpha=0,05$ ) terhadap Earning Per Share.2) Koefisien regresi variabel $\mathrm{X}_{2}$ bertanda negatif menunjukkan adanya hubungan yang negatif dari variabel Debt To Equity Ratio yang menyebabkan penurunan sebesar -168,672 dan signifikan untuk prob sig 0.000 (signifikansi untuk $\alpha=0,05$ ) terhadap Earning Per Share 3) Koefisien regresi variabel $\mathrm{X}_{3}$ bertanda positif menunjukkan adanya hubungan yang positif dari variabel PDB yang menyebabkan kenaikan sebesar 2390,044 dan signifikan untuk prob sig 0.000 (signifikansi untuk $\alpha=0,05$ ) terhadap Earning Per Share

Dari hasil analisis dapat diketahui bahwa variabel bebas yang paling berpengaruh adalah variabel PDB dengan koefisien 2390,044. Sedangkan variable BV dan DER memberikan pengaruh negatif terhadap EPS, yang berarti meningkatnya BV dan DER mengakibatkan menurunnya EPS.

Dari persamaan diatas menginformasikan bahwa perubahan variabel independen internal Produk Domestik Bruto berpengaruh positif dan signifikan terhadap perubahan EPS, sedangkan perubahan variabel eksternal perusahaan yaitu perubahan BV berpengaruh negatif dan tidak signifikan terhadap perubahan harga saham serta perubahan DER berpengaruh negatif dan tidak signifikan terhadap perubahan EPS.

Terlihat pada angka R square atau koefisien determinasi yaitu 0,638 artinya, Book Value, Debt to Equity Ratio), Produk Domestik Bruto memberikan kontribusi sebesar 63,8\% terhadap Earning Per Share sedangkan sisanya 36,2\% dipengaruhi oleh faktor-faktor lain di luar model penelitian, seperti kondisi ekonomi, kebijakan pemerintah, dan fundamental perusahaan lainnya.

\section{KESIMPULAN DAN SARAN}




\section{Kesimpulan}

Penelitian ini diperoleh kesimpulan bahwa hasil uji secara simultan atau secara serempak (Uji-F) menunjukkan nilai F 21,184 dengan tingkat signifikansi 0,000. Hal tersebut menunjukkan bahwa variabel independen yang terdiri dari Book Value, Debt to Equity Ratio, dan Produk Domestik Bruto berpengaruh positif dan signifikan terhadap Earning Per Share pada PT.Unilever Indonesia, Tbk. dari tahun 2006 - 2015, memberikan kontribusi sebesar 63,8\% terhadap Earning Per Share sedangkan sisanya 36,2\% dipengaruhi oleh faktor-faktor lain di luar model penelitian, seperti kondisi ekonomi, kebijakan pemerintah, dan fundamental perusahaan lainnya.

\section{Saran}

Untuk penelitian selanjutnya sebaiknya ditambah jumlah periode penelitian dan menggunakan bentuk analisis yang berbeda.Untuk peneliti selanjutnya, diusahakan perusahaan yang menjadi sampel penelitian bisa dibedakan dari penelitian ini. Mungkin dengan berbedanya sampel penelitian yang diambil, maka variabel Book Value, Debt to Equity Ratio dan Produk Domestik Bruto, bisa berpengaruh positif terhadap variabel Earning Per Share. Meskipun dalam penelitian ini ternyata Book Value, Debt to Equity Ratio secara simultan berpengaruh negatif terhadap Earning Per Share.

\section{DAFTAR PUSTAKA}

Ang, Robert.1997. Buku Pintar Pasar Modal Indonesia. Jakarta: Media Staff Indonesia Frank J Fabozzi.1999. Manajemen Investasi. Jakarta: salemba empat

Iqbal Widya Nanda.2011. Berdasarkan hasil uji secara parsial DER berpengaruh negativf tidak signifikan terhadap EPS, ROA berpengaruh positif dan signifikan terhadap EPS serta ROE berpengaruh positif dan signifikan terhadap EPS. Oleh karena itu peneliti tertarik untuk menambahkan variabel Book Value dan Produk Domestik Bruto dengan DER terhadap EPS, yang memungkinkan DER berpengaruh positif terhadap EPS.

Jogiyanto. 2008. Teori Portofolio dan Analisis Investasi. Yogyakarta :BPFE

Mankiw. 2000. Teori Makroekonomi. Jakarta : Erlangga

Riyanto, Bambang. 2008. Dasar-dasar Pembelajaran Perusahaan. Yogyakarta :BPFE

Sihombing,Gregorius.2008.Kaya dan Pintar jadi Traider dan Investor Saham. Yogyakarta : Indonesia Cerdas

Suparning, budhi. Tari, DMR. Utomo, FC. 2018. Effect Of Stock Price Return on Asset, Earning Per Share, Price Earning Ratio, and Firm Size On Income Smoothing In Indonesia Manufacturing Industry, Vol. 6 (33), pp. 290-297. 
